\title{
Extraosseous Uptake of 99mTc-HMDP to SPECT-CT Suggesting Hyperfixing Kidney Stone
}

\section{Serigne M Badiane $\mathbf{1}^{1^{*}}$, Kalidou Gueye ${ }^{2}$ and Oumar Ndoye ${ }^{2}$}

${ }^{1}$ Biophysics and Nuclear Medicine, Gaston Berger University, Saint-Louis, Senegal

${ }^{2}$ Biophysics and Nuclear Medicine, Cheikh Anta Diop de Dakar University, Senegal

"Corresponding author: Serigne M Badiane, Biophysics and Nuclear Medicine, Faculty of Health Sciences, Gaston Berger University of Saint- Louis, Senegal, E-mail: drmoussabadiane@gmail.com

Received date: February 05, 2019; Accepted date: March 06, 2019; Published date: March 16, 2019

Copyright: $\odot 2019$ Badiane SM, et al. This is an open-access article distributed under the terms of the Creative Commons Attribution License, which permits unrestricted use, distribution, and reproduction in any medium, provided the original author and source are credited.

Keywords: Extra-bone uptake; Kidney stone; 99mTc-HMDP

\section{Introduction}

Bone scintigraphy $99 \mathrm{mTc}-\mathrm{HMDP}$ is still the most common examination in nuclear medicine. Its high sensitivity but the fixations are not specific and the presence of extra bone fixation can be observed in several physiological or pathological situations. This extra-bone uptake has been the subject of several studies. The fact remains that they always arouse curiosity in certain clinical situations with a risk of misdiagnosis. We report here a case of extra-osseous fixation giving an atypical image simulating a hyper fixing kidney stone.

\section{Case Report}

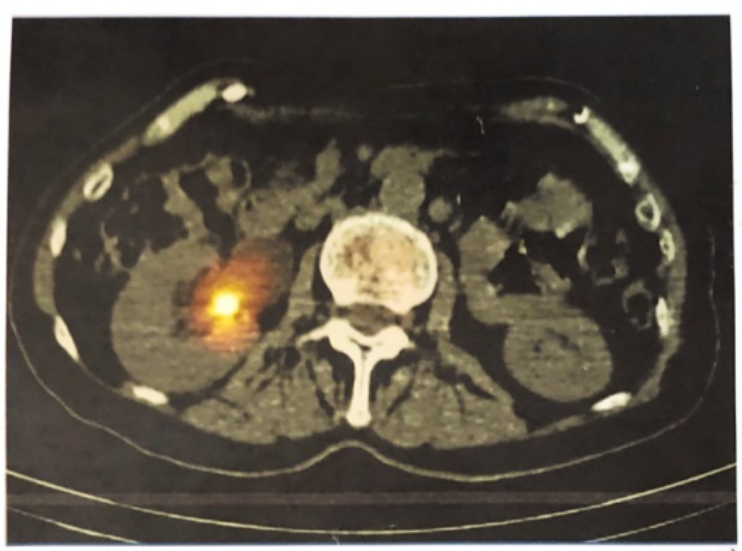

Figure 1: Abdominal SPECT-CT scan at the level of kidneys.

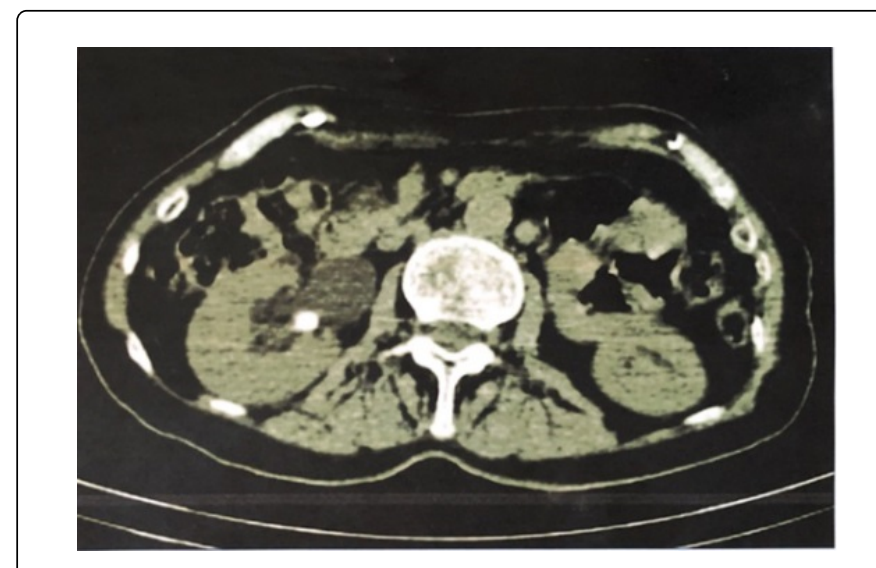

Figure 2: Abdominal CT scan at the level of kidneys.

A 43-year-old female without a history of a particular medicalsurgical disease was received for a bone scintigraphy in the presence of lumbo-sacral pain which has been evolving for a month. She was examined by bone scintigraphy, after injection of $740 \mathrm{MBq}$ of $99 \mathrm{mTc}-$ HMDP with a SPECT-CT Symbia $\mathrm{T}$ hybrid camera with a high resolution low energy collimator.

The images were acquired on a $512 \times 1024$ matrix with a scanning speed of $12 \mathrm{~cm} / \mathrm{min}$. The images obtained 3 hour after injection revealed an intense uptake over the area of a left pelvic kidney stone. Furthermore, the skeletal examination was normal (Figures 1-3). At first glance, these rare images were suggestive of a hyperfixed kidney stone. 


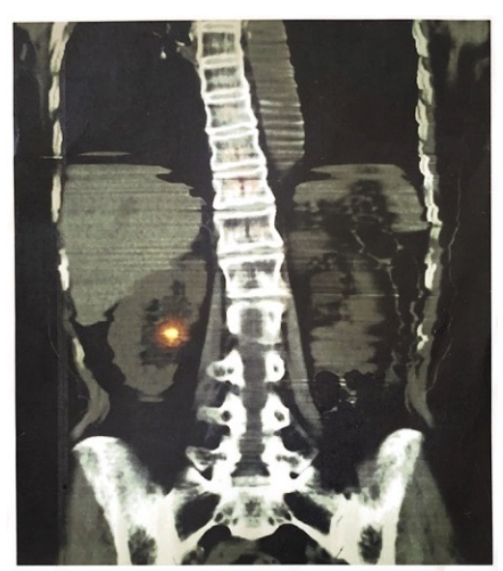

Figure 3: Sagittal cut SPECT-CT.

\section{Discussion}

These images aroused our curiosity for a literature review and discussion on extra-bone uptake. The uptaking mechanism of technetium biphosphonates remains complex and poorly understood. Several sometimes contradictory theories have been put forward. It is the fixation on the organic phase of the bone of fixation on the mineral phase of the bone and the cellular fixation after internalization in osteoclasts and osteoblasts.

Today, it is recognized that setting preferentially operates in wellperfused areas and where there is an active osteogenesis. The organic matrix of bone is essentially composed of collagen and is secreted by osteoblasts. On this basis are deposited the inorganic salts comprising calcium ions and phosphates.

Calcium phosphate is initially amorphous form and present in different hydration states. From that initial deposit will form the hydroxyapatite crystals. Other ions are also present in the mineral matrix of the bone, such as magnesium, sodium, potatium and bicarbonate.

This ability of hydroxyapatite crystals to adsorb at their surface many types of ions extends to bodies that are not normally present in the body, such as strontium [1]. In bone scintigraphy technetium-99mlabeled bisphosphonates bind to hydroxyapatite crystals and fixation is more intense in areas with increased osteoblastic activity.

Clinical experience has demonstrated some aspects of extra-bone fixation of $99 \mathrm{mTc}-\mathrm{HMDP}$ but has not been able to determine its mechanism with certainty. 99mTc-Bisphosphonate binding affects a wide range of non-bone abnormalities. Many cases of this type of fixation have been reported. Pathological entities such as neoplasia, inflammation, ischemia, trauma, and scintigraphic artifacts illustrate the abnormal uptake of this type of radiopharmaceutical to extraskeletal soft tissues. The mechanisms of fixation of bone tracer on soft tissues are not univocal and are often entangled.

One of the most frequent mechanisms involved is the simple passive diffusion of the tracer in an interstitial sector increased volume. This increase in volume of the interstitial fluid can occur in many circumstances: inflammatory and tumoral phenomena, renal failure, amyloidosis, rhabdomyolysis, pleural effusions or ascites [2].
The existence of calcifications is also frequently questioned. Indeed, 99mTc-HMDP binding is proportional to the calcium content of the tissues. The fixations are then visible mainly in acid $\mathrm{pH}$ tissues such as the stomach, lungs and kidneys. The presence of other metal ions is decisive in the reactivity of the bisphosphonates with respect to calcium concretions. On the other hand, the addition of magnesium significantly reduces this reactivity [3].

Other mechanisms mentioned involve the binding of the osteotropic tracer to denatured proteins, immature collagen, ferric deposits or directly to certain tumor receptors [4]. The role of hyperaemia or an alteration of capillary permeability has also been mentioned [5]. In amyloidosis, fixation concerns both types of amyloid deposits, AA and AL types [6]. Extra-osseous ossifications have the same affinity for bisphosphonates as normal bone [7]. Artifacts that can be mistaken for ectopic fixations are usually due to a lack of radiopharmaceutical preparation [8].

We reminded that the extra-bone uptakes of 99mTc-HMDP are of accidental discovery and mainly concern calcium metastases and heterotopic bone formations. The sites of predilection for extraosseous fixation are mainly the kidneys and the bladder. In certain pathological situations we can find fixations on soft tissue in the stomach, spleen frequently in sickle cell disease, liver in chronic or malignant inflammatory diseases, muscles and lungs. The causes are multiple and the mechanisms unclear [3].

However, among the causes of extra bone uptake we can report the conditions of preparation of the radiopharmaceutical product [8] and the drug interference also the Tracer diffusion, the disruption of the calcium metabolism or the deposition of ferric ions [9]. Lithogenesis, on the other hand, depends on a mechanical process. It results from the saturation of the urine followed by crystallization favored by oxalates, phosphates and purines which give crystals aggregating one on top of the other [10].

Some lithogenic processes are still questionable, such as the formation of Randall plates. These are papillary calcification processes initially developed in the interstitium. These calcifications will support the formation of oxalocalcic stones after a break-in on the surface of the papillary epithelium [11]. Despite the atypical nature of this image, the current state of knowledge on the physico-chemical and physiological mechanisms of biphosphonate fixation does not lead us to extra-bone fixation on a kidney stone.

It is however legitimate to explore whether, is that in urinary retention pyéllique prolonged contact of the tracer with the calculus may result by ion exchange process fixing the 99mTc-HMDP on the stone.

\section{Conclusion}

In conclusion, we found that these atypical images correspond to pyelic retention of the radiant tracer on the surface of a kidney stone. It thus produces an effect simulating a hyperfixed kidney stone. This image refers to that of an actor in the spotlight unwittingly. This isolated case is of scientific interest for a trap image in bone scintigraphy. A cautious reading backed by a scientific argument is always necessary for a good interpretation of the images in 99mTcHMDP bone scintigraphy with high sensitivity and low specificity. 
Citation: Badiane SM, Gueye K, Ndoye O (2019) Extraosseous Uptake of 99mTc-HMDP to SPECT-CT Suggesting Hyperfixing Kidney Stone. J Nucl Med Radiat Ther 10: 397. doi:10.4172/2155-9619.1000397

Page 3 of 3

\section{References}

1. Paycha F, Richard B (2001) Exploration scintigraphique du squelette. Encycl Méd Chir. Radiodiagnostic-Squelette normal 30: 480.

2. Worsley DF, Lentle BC (1993) Uptake of technetium-99m MDP in primary amyloidosis with a review of the mechanisms of soft tissue localization of bone seeking radiopharmaceuticals. Journal of nuclear medicine: Official publication. Society of Nuclear Medicine 34: 1612-1615.

3. Peller P, Ho VB, Kransdorf MJ (1993) Extraosseous Tc-99m MDP uptake: A pathophysiologic approach. Radiographics 13: 715-734.

4. Ibis E, Krasnow AZ, Isitman AT, Akansel G, Erbay G, et al. (1992) Liver uptake of technetium-99m-labeled phosphate compounds: An update Gamut. Semin Nucl Med 22: 202-205.

5. Brill DR (1981) Radionuclide imaging of nonneoplastic soft tissue disorders. Semin Nucl Med 11:277-288.
6. Janssen S, Piers DA, Rijswijk MH, Meijer S, Mandema E (1990) Softtissue uptake of $99 \mathrm{~m}$-Tc-diphosphonate and $99 \mathrm{~m}$ Tc-pyrophosphate in amyloidosis. Eur J Nucl Med 16: 663-670.

7. Loutfi I, Collier BD, Mohammed AM (2003) Nonosseous abnormalities on bone scans. J Nucl Med Technol 31: 149-153.

8. Abedi SM, Babaee AR, Sadeghi M, Sadeghzadeh N (2014) Radionuclide, Radiochemical and Chemical Evaluation of Elutes Obtained from 99 $\mathrm{Mo} / 99 \mathrm{~m}$ Tc Generators. Journal of Mazandaran University of Medical Sciences 24: 220-224.

9. Van JA, Hall JN, O'Mara RE (1977) Soft-tissue concentration of Tc-99m phosphates associated with injections of iron dextran complex. J Nucl Med 18: 855-855.

10. Daudon M, Traxer O, Lechevallier E, Saussine C (2008) La lithogenèse. Progrès en urologie, 18: 815-827.

11. Randall A (1936) An hypothesis for the origin of renal calculus. N Engl J Med 214: 234-242. 